\title{
KONTRIBUSI MOTIVASI BELAJAR DAN LINGKUNGAN BELAJAR TERHADAP HASIL BELAJAR PADA MATA PELAJARAN KESELAMATAN DAN KESEHATAN KERJA (K3) DI SMK NEGERI 1 MAGELANG TAHUN AJARAN 2019/2020
}

\author{
Dwi Apri Kristiyanto*1, Tawardjono Us ${ }^{1}$ \\ ${ }^{1}$ Jurusan Pendidikan Teknik Otomotif, Universitas Negeri Yogyakarta \\ Corresponding Author: dwi.apri2015@student.uny.ac.id
}

\begin{abstract}
Abstrak
Penelitian ini bertujuan untuk mengetahui : (1) Kontribusi Motivasi Belajar terhadap Hasil Belajar siswa Teknik Kendaraan Ringan SMK Negeri 1 Magelang, (2) Kontribusi Lingkungan Belajar terhadap Hasil Belajar siswa Teknik Kendaraan Ringan SMK Negeri 1 Magelang, (3) Kontribusi Motivasi Belajar dan Lingkungan Belajar secara bersama-sama terhadap Hasil Belajar siswa Teknik Kendaraan Ringan SMK Negeri 1 Magelang. Populasi dalam penelitian ini adalah siswa kelas X TKR SMK Negeri 1 Magelang dengan jumlah 96 siswa. Pengumpulan data dilakukan dengan angket dan dokumentasi. Angket untuk mengumpulkan data Motivasi Belajar dan Lingkungan Belajar sedangkan dokumentasi untuk mengambil data Hasil Belajar. Analisis data yang digunakan teknik analisis regresi sederhana untuk hipotesis pertama dan hipotesis kedua serta analisis regresi ganda untuk hipotesis ketiga. Hasil penelitian ini : (1) Motivasi Belajar secara parsial memiliki kontribusi sebesar 21,7\% terhadap Hasil Belajar siswa. Uji signifikansi menggunakan Uji t dengan hasil penghitungan yang menunjukan nilai thitung lebih besar dari tabel $(8,996>1,985)$ pada taraf signifikansi 0,05 dengan koefisien korelasi sebesar 0,680 sehingga dikatakan kontribusinya signifikan. (2) Lingkungan Belajar secara parsial memiliki kontribusi sebesar 32,6\% terhadap Hasil Belajar siswa. Uji signifikansi menggunakan Uji t dengan hasil penghitungan yang menunjukan nilai thitung lebih besar dari tabel $(9,780>1,985)$ pada taraf signifikansi 0,05 dengan koefisien korelasi sebesar 0,710 sehingga dikatakan kontribusinya signifikan. (3) Motivasi Belajar dan Lingkungan Belajar secara simultan memiliki kontribusi sebesar 54,3 terhadap Hasil Belajar siswa. Uji signifikansi menggunakan Uji $\mathrm{F}$ dengan hasil penghitungan yang menunjukan nilai Fhitung lebih besar dari Ftabel $(55,270>3,09)$ pada taraf signifikansi 0,05 dengan koefisien determinasi sebesar 0,543 sehingga dikatakan kontribusinya signifikan.
\end{abstract}

\section{Kata kunci: kontribusi, motivasi belajar, lingkungan belajar dan hasil belajar. Abstract}

This research aims to find out : (1) Contribution of Learning Motivation to Learning Results of Light Vehicle Engineering Students at SMK Negeri 1 Magelang, (2) Contribution of Learning Environment to Learning Results of Light Vehicle Engineering Students at SMK Negeri 1 Magelang, (3) Contribution of Learning Motivation and Learning Environment simultaneously to the Learning Results of Light Vehicle Engineering students at SMK Negeri 1 Magelang. This study was a population study where the population used was the grade X TKR SMK Negeri 1 Magelang, totaling 96 students. Data collection was carried out through questionnaires and documentation. The data analysis used was a simple regression analysis technique for the first hypothesis and the second hypothesis, and multiple regression analysis for the third hypothesis. The results obtained from this study were: (1) Learning motivation 
partially had a contribution of $21.7 \%$ to student learning results. The significance test performed using the $t$ test showed that the value of tcount was greater than $t$ table (8.996> 1.985 ) at a significance level of 0.05 with a correlation coefficient of 0.680 , which means that the contribution is said to be significant. (2) The learning environment partially contributed $32.6 \%$ to student learning results. The significance test using the $t$ test showed that the value of tcount was greater than table (9.780> 1.985) at a significance level of 0.05 with a correlation coefficient of 0.710 so that it can be said that the contribution is significant. (3) Learning Motivation and Learning Environment simultaneously had a contribution of 54.3 to student learning results. The significance test using the $\mathrm{F}$ test showed that the value of Fcount was greater than Ftable (55.270> 3.09) at the significance level of 0.05 with a determination coefficient of 0.543 which means that the contribution is significant.

\section{Keywords: contribution, learning motivation, learning environment and learning results.}

\section{PENDAHULUAN}

Proses pembelajaran merupakan naluri alamiah setiap orang untuk menemukan apa yang tidak mereka mengerti dalam hidupnya. Naluri ilmiah kemudian dikemas menjadi suatu model pembelajaran di dalam kelas. Naluri ilmiah yang ada dalam diri seseorang akan dilaksanakan dalam pembelajaran teknik kendaraan ringan yaitu mata pelajaran Keselamatan dan Kesehatan Kerja (K3).

Mata pelajaran Keselamatan dan Kesehatan Kerja (K3) bertujuan untuk mempelajari tentang prosedur pada tempat kerja untuk mengidentifikasi bahaya dan pencegahannya, pemeliharaan lingkungan kerja, perlengkapan yang diperlukan agar pekerjaannya lebih aman, pelaksanakan prosedur darurat, mengetahui dasar-dasar keamanan, dan mengikuti prosedur tempat kerja. Sehingga ilmu atau materi pelajaraan ini sangat penting dimiliki siswa sehingga dalam praktik di sekolahan maupun di tempat kerja siswa dapat mengaplikasikan dengan baik. Karena materi pelajaran ini sangatlah penting maka ilmu ini harus dikuasai oleh siswa. Penguasaan K3 siswa dapat dilihat dari sikap dan perilakunya pada saat melaksanakan praktik di bengkel.

Dari hasil observasi yang sudah dilakukan pada saat PPL di SMK Negeri 1 Magelang, didapat bahwa sikap, perilaku dan keaktifan siswa dalam materi pelajaran K3 masih belum memenuhi kriteria minimum. Kriteria minimum dilihat dari terdapat syarat penerapan K3 yang belum diterapkan antara lain tidak menggunakan baju praktek yang lengkap, tidak menggunakan alat pelindungan diri yang tepat, proses praktek yang tidak sesuai sop, tidak menjaga kebersihan dan melaksanakan praktek tidak tertib. Sehubungan dengan sikap dan perilaku siswa dalam peranan materi pelajaran sangatlah penting karena di dalam bengkel praktek ataupun di industri nantinya akan banyak sekali resiko-resiko yang ditimbulkan jika 
tidak berhati-hati dan teliti dalam bekerja. Materi harus dikuasai oleh siswa dan setelah dilakukan observasi menunjukan bahwa sikap dan perilaku siswa dalam materi pelajaran masih tergolong rendah karena siswa dalam melaksanakan praktek belum mengikuti prosedur kerja dengan baik dan teliti.

Siswa dalam melaksanakan praktek belum mengikuti dengan baik dan teliti diakibatkan oleh kurangnya rasa ingin tahu siswa dan kurangnya siswa dalam membaca ataupun kurangnya siswa dalam memotivasi diri untuk belajar. Motivasi belajar merupakan hal yang sangat penting dalam mempelajari suatu materi pelajaran. Motivasi mengaktifkan dan mengarahkan perilaku seseorang untuk berkata, bertindak, dan melakukan sesuatu hal (Afifi \& Sukaswanto, 2020; Sjukur, 2012; Slavin, 2009). Tidak terlepas dari motivasi belajar, minat dari setiap siswa dan juga lingkungan memiliki peranan yang penting dalam belajar suatu materi di SMK.

Dari permasalahan diatas, penelitian ini bertujuan untuk mengetahui seberapa besar kontribusi antara Motivasi Belajar dan Lingkungan Belajar terhadap Hasil Belajar siswa pada mata pelajaraan Keselamatan dan Kesehatan Kerja di SMK Negeri 1 Magelang.

\section{METODE}

Penelitian ini merupakan penelitian kuantitatif yang berarti semua informasi atau data diwujudkan dalam angka dan analisisnya berdasarkan analisis statistik yang berupa angka. Untuk mendapatkan data dari variabel motivasi belajar dan lingkungan belajar dalam penelitian ini menggunakan angket sedangkan variabel hasil belajar menggunakan dokumentasi. Data yang sudah terkumpul akan diproses dengan dua tahap, yaitu tahap pengujian prasyarat analisis dan tahap pengujian hipotesis. Pengujian prasyarat analisis terdiri dari Uji Normalitas yang menggunakan uji kolmogorov smirnov dengan dasar pengambilan keputusan jika nilai signifikansi lebih dari 0,05 maka nilai residual berdistribusi normal dan jika nilai signifikansi kurang dari 0,05 maka nilai residual tidak berdistribusi normal. Uji Multikolinearitas dapat dilihat dari nilai VIF dan nilai tolerance dengan dasar pengambilan keputusan jika nilai tolerance lebih besar dari 0,10 maka tidak terjadi multikolieneritas dan jika nilai VIF lebih kecil dari 10 maka tidak terjadi multikolieneritas. Uji linearitas dengan dasar jika nilai signifikansi deviation from linearity kurang dari 0,05 maka tidak terdapat hubungan antara variabel bebas dengan variabel terikat. 
Tahap kedua pengujian hipotesis mengunakan analisis regresi sederhana dan analisis regresi ganda. Analisis Regresi Sederhana digunakan untuk mengetahui pengaruh variabel bebas terhadap variabel terikat secara individual. Adapun pengaruh variabel bebas terhadap variabel terikat secara individual yaitu Motivasi Belajar terhadap Hasil Belajar, Lingkungan Belajar terhadap Hasil Belajar. Analisis Regresi Ganda digunakan untuk mengetahui pengaruh variabel Motivasi Belajar dan Lingkungan belajar secara simultan terhadap Hasil belajar.

\section{HASIL \& PEMBAHASAN}

\section{HASIL}

Pengujian dari regresi sederhana bertujuan untuk mengetahui signifikansi masing-masing hubungan antara Motivasi Belajar (X1) terhadap Hasil Belajar (Y) (rX1Y) dan Lingkungan Belajar (X2) terhadap Hasil Belajar (Y) (rX2Y). Uji signifikansi ini menggunakan uji t. Kriteria yang digunakan jika thitung lebih besar dari ttabel maka berkontribusi signifikan dan sebaliknya. Hasil thitung dari $\mathrm{rX} 1 \mathrm{Y}=8,996$ yang lebih dari ttabel 1,985 (taraf signifikansi 5\%) dapat dikatakan bahwa Motivasi Belajar (X1) mempunyai kontribusi yang signifikan terhadap Hasil Belajar (Y) siswa kelas X TKR SMK Negeri 1 Magelang tahun ajaran 2019/2020, maka hipotesis pertama dapat diterima. Selanjutnya hasil thitung dari rX2Y = 9,780 yang lebih besar dari ttabel 1,985 (taraf signifikansi 5\%) dapat dikatakan bahwa Lingkungan Belajar (X2) mempunyai kontribusi yang signifikan terhadap Hasil Belajar (Y) siswa kelas X TKR SMK Negeri 1 Magelang tahun ajaran 2019/2020, maka hipotesis kedua dapat diterima.

Pengujian regresi ganda dengan mencari harga $\mathrm{Ry}(1,2)$ sebesar 0,737 , yang menunjukkan pengaruh positif Motivasi Belajar dan Lingkungan Belajar secara bersama-sama terhadap Hasil Belajar. Koefisien determinasi $\left(\mathrm{R}^{2}\right)$ sebesar 0,543, berarti bahwa Motivasi Belajar dan Lingkungan Belajar secara bersama-sama memiliki kontribusi sebesar 54,3\% untuk meningkatkan Hasil Belajar. Hal ini menunjukkan masih ada 45,7\% faktor atau variabel lain yang dimungkinkan berpengaruh terhadap Hasil Belajar selain Motivasi Belajar dan Lingkungan Belajar. Dengan demikian dapat dikatakan bahwa jika terdapat peningkatan Motivasi Belajar dan Pengondisian Lingkungan Belajar yang baik maka Hasil Belajar juga akan meningkat. 
Berdasarkan uji F dengan bantuan program SPSS 16.00 for Windows, diperoleh nilai Fhitung sebesar 55,270 jika dibandingkan dengan Ftabel sebesar 3,09 pada taraf signifikansi $5 \%$ maka nilai Fhitung > Ftabel $(55,270>3,09)$. Hal ini berarti bahwa terdapat kontribusi positif dan signifikan Motivasi Belajar dan Lingkungan Belajar secara bersama-sama terhadap Hasil Belajar seluruh siswa kelas X TKR SMK Negeri 1 Magelang tahun ajaran 2019/2020. Dengan demikian maka dapat dikatakan hipotesis ketiga diterima.

\section{PEMBAHASAN}

Hasil penelitian ini menunjukkan bahwa terdapat kontribusi positif dan signifikan antara Motivasi Belajar dengan Hasil Belajar. Melalui analisis regresi sederhana dengan bantuan program SPSS 16.00 for Windows, maka diperoleh koefisien korelasi sebesar 0,680. Harga rtabel dengan N-96 pada taraf signifikansi 5\% sebesar 0,1986. Hal itu berarti rhitung lebih besar dari rtabel $(0,680>0,1986)$. Selain itu juga diperoleh harga thitung sebesar 8,996 dan ttabel 1,985 dengan taraf signifikansi 5\% sedangkan hasil penghitungan sumbangan efektif dari koefisien regresi dan koefisien korelasi dikalikan 100\% menunjukkan nilai sebesar 21.7\%. Nilai tersebut dapat membuktikan hipotesis diterima, yang berarti bahwa "Ada Kontibusi Motivasi Belajar terhadap Hasil Belajar siswa pada mata pelajaran Keselamatan dan Kesehatan Kerja (K3)”.

Motivasi Belajar merupakan daya penggerak yang berasal dari dalam diri individu untuk melakukan kegiatan belajar. Individu yang memiliki Motivasi Belajar yang tinggi akan berusaha melaksanakan kegiatan belajar tersebut dengan semangat yang tinggi. Motivasi Belajar dapat berasal dari dalam diri individu dan luar diri individu. Motivasi belajar yang datang dari dalam berupa dorongan dari hati sanubari, sedangkan Motivasi Belajar yang datang dari luar berupa dorongan dari orang tua, teman-teman, dan anggota masyarakat. Apabila dalam diri siswa sudah tertanam Motivasi Belajar yang tinggi maka siswa akan lebih bersemangat dalam mengikuti kegiatan belajar dan akan semakin mudah bagi siswa dalam menyerap mata pelajaran yang disampaikan oleh guru.

Hasil penelitian ini menunjukkan bahwa terdapat kontribusi positif dan signifikan antara Lingkungan Belajar dengan Hasil Belajar. Melalui analisis regresi sederhana dengan bantuan program SPSS 16.00 for Windows, maka diperoleh koefisien korelasi sebesar 0,710. Harga rtabel dengan N-96 pada taraf signifikansi 5\% sebesar 0,1986. Hal itu berarti rhitung lebih besar dari rtabel $(0,710>0,1986)$. Selain itu juga diperoleh harga thitung sebesar 9,780 dan 
ttabel 1,985 dengan taraf signifikansi 5\% sedangkan hasil penghitungan sumbangan efektif dari koefisien regresi dan koefisien korelasi dikalikan 100\% menunjukkan nilai sebesar 32,6\%. Nilai tersebut dapat membuktikan hipotesis diterima, yang berarti bahwa "Ada Kontribusi Lingkungan Belajar terhadap Hasil Belajar siswa pada mata pelajaran Keselamatan dan Kesehatan Kerja (K3)".

Lingkungan Belajar mempunyai pengaruh positif dan signifikan terhadap Hasil Belajar siswa pada mata pelajaran Keselamatan dan Kesehatan Kerja (K3). Hal ini memperkuat deskripsi teoritik bahwa semakin baik atau kondusifnya Lingkungan Belajar mempengaruhi Hasil Belajar semakin optimal sebagaimana yang diungkapkan para ahli. Lingkungan pendidikan merupakan segala sesuatu yang melingkupi proses berlangsungnya pendidikan (Arif Rochman, 2009: 195), dengan demikian dapat dikatakan bahwa semakin kondusif Lingkungan Belajar akan semakin tinggi pula Hasil Belajar siswa pada mata pelajaran Keselamatan dan Kesehatan Kerja (K3), dan sebaliknya jika Lingkungan Belajar siswa kurang kondusif maka Hasil Belajar siswa pada mata pelajaran Keselamatan dan Kesehatan Kerja (K3) akan semakin rendah pula.

Hasil penelitian ini menunjukkan bahwa terdapat kontribusi positif dan signifikan antara Motivasi Belajar dan Lingkungan Belajar secara bersama-sama terhadap Hasil Belajar. Melalui analisis regresi ganda dengan bantuan program SPSS 16.00 for Windows, maka diperoleh koefisien korelasi sebesar 0,737. Harga rtabel dengan N-96 pada taraf signifikansi $5 \%$ sebesar 0,1986. Hal itu berarti rhitung lebih besar dari rtabel $(0,737>0,1986)$. Selain itu juga diperoleh harga fhitung sebesar 55,270 dan ftabel 3,09 dengan taraf signifikansi 5\% hasil penghitungan tersebut berarti fhitung lebih besar dari ftabel $(55,270>3,09)$ sehingga $b$ dapat disimpulkan bahwa Motivasi Belajar dan Lingkungan Belajar secara bersama-sama mempunyai pengaruh positif dan signifikan terhadap hasil belajar. Sedangkan hasil penghitungan sumbangan efektif dari koefisien determinasi menunjukkan nilai sebesar 54,3\%. Nilai tersebut dapat membuktikan bahwa "Ada Kontribusi Motivasi Belajar dan Lingkungan Belajar secara simultan terhadap Hasil Belajar siswa pada mata pelajaran Keselamatan dan Kesehatan Kerja (K3)".

Motivasi Belajar dan Lingkungan Belajar mempunyai pengaruh positif dan signifikan terhadap Hasil Belajar siswa pada mata pelajaran Keselamatan dan Kesehatan Kerja (K3). Hal ini memperkuat deskripsi teoritik bahwa semakin baik atau tingginya Motivasi Belajar serta semakin baik atau kondusifnya Lingkungan Belajar mempengaruhi Hasil Belajar siswa pada 
mata pelajaran Keselamatan dan Kesehatan Kerja (K3) semakin optimal sebagaimana yang diungkapkan para ahli. Motivasi Belajar dan Lingkungan Belajar yang baik secara bersamasama akan meningkatkan kemauan dan semangat belajar siswa untuk mencapai Hasil Belajar siswa pada mata pelajaran Keselamatan dan Kesehatan Kerja (K3) yang lebih optimal. Dengan demikian dapat dikatakan bahwa semakin baik Motivasi Belajar dan Lingkungan Belajar akan semakin tinggi pula Hasil Belajar siswa pada mata pelajaran Keselamatan dan Kesehatan Kerja (K3), dan sebaliknya jika Motivasi Belajar dan Lingkungan Belajar siswa kurang baik maka Hasil Belajar siswa pada mata pelajaran Keselamatan dan Kesehatan Kerja (K3) semakin rendah pula.

\section{SIMPULAN}

Berdasarkan hasil penilaian dan pembahasan yang telah diuraikan, maka dapat diambil kesimpulan bahwa motivasi Belajar secara parsial memiliki kontribusi sebesar 21,7\% terhadap Hasil Belajar siswa. Uji signifikansi menggunakan Uji t dengan hasil penghitungan yang menunjukan nilai thitung lebih besar dari ttabel $(8,996>1,985)$ pada taraf signifikansi 0,05 dengan koefisien korelasi sebesar 0,680 sehingga dikatakan kontribusinya signifikan. Lingkungan Belajar secara parsial memiliki kontribusi sebesar 32,6\% terhadap Hasil Belajar siswa. Uji signifikansi menggunakan Uji t dengan hasil penghitungan yang menunjukan nilai thitung lebih besar dari ttabel $(9,780>1,985)$ pada taraf signifikansi 0,05 dengan koefisien korelasi sebesar 0,710 sehingga dikatakan kontribusinya signifikan. Motivasi Belajar dan Lingkungan Belajar secara simultan memiliki kontribusi sebesar 54,3 terhadap Hasil Belajar siswa. Uji signifikansi menggunakan Uji f dengan hasil penghitungan yang menunjukan nilai fhitung lebih besar dari ftabel $(55,270>3,09)$ pada taraf signifikansi 0,05 dengan koefisien determinasi sebesar 0,543 sehingga dikatakan kontribusinya signifikan.

\section{DAFTAR PUSTAKA}

Afifi, M., \& Sukaswanto, S. (2020). Pengaruh kompetensi siswa dan peran serta bkk terhadap motivasi untuk bekerja di bidang otomotif siswa kelas XI jurusan teknik kendaraan ringan SMK se-Kabupaten Bantul. Jurnal Pendidikan Vokasi Otomotif, 2(2), 61-70.

Arikunto, Suharsimi. (2006). Prosedur Penelitian : Suatu Pendekatan Praktik Edisi Revisi V. Jakarta: Rineka Cipta. 
Djaafar, Hj. Tengku Zahara. (2001). Kontribusi Strategi Pembelajaraan Terhadap Hasil Belajar. Jakarta: Universitas Negeri Padang.

Hadi, Sutrisno. (2004). Analisis Regresi. Yogyakarta: Andi Yogyakarta.

Sjukur, S. B. (2012). Pengaruh blended learning terhadap motivasi belajar dan hasil belajar siswa di tingkat SMK. Jurnal pendidikan vokasi, 2(3).

Slavin, R.E. (2009). Psikologi pendidikan teori dan praktik, edisi kedelapan, Jilid kedua (Terjemahan Marianto Samosir). Jakarta: PT Index (Buku asli diterbitkan tahun 2006).

Sugiono. (2010). Statistika untuk Penelitian. Bandung: Alfabeta.

Sugiono. (2013). Metode Penelitian Kuantitatif, Kualitatif, dan R\&D. Bandung: Alfabeta. 